\title{
PENDIDIKAN ISLAM PERSPEKTIF AL-QURAN SURAT LUQMAN AYAT 13-17 DAN IMPLIKASINYA PADA PENDIDIKAN KELUARGA
}

\author{
Toha Makhshun 1) * \\ ${ }^{1}$ Universitas Islam Sultan Agung \\ *E-mail: toha_m@unissula.ac.id
}

\begin{abstract}
The article is to find out the concept of Islamic Education contained in Surat Luqman, especially verses 13-17, and to disseminate the implications of Islamic education in Surat Luqman verses 13-17 on family education. The analysis used is descriptive interpretive, namely interpreting the data with deductive and inductive thinking methods. The result is that in the letter Luqman verses 13-17 there are three hierarchical concepts of education, namely faith education, moral education, and worship education. The implication is that the soul of the child will be planted with the spirit of tauhid, do good to both parents, and perform prayers on time, and get the pleasure of Allah SWT.
\end{abstract}

Keywords: Islamic Education, Surat Luqman Verses 13-17, Family Education

\begin{abstract}
Abstrak
Artikel ini bertujuan untuk mengetahui konsep Pendidikan Islam yang terdapat pada Surat Luqman khususnya ayat 13 - 17, dan untuk menyebar luaskan Implikasi Pendidikan Islam pada Surat Luqman ayat 13 - 17 terhadap Pendidikan Keluarga. Analisis yang digunakan adalah deskripstif interpretatif, yaitu menginterpretasi data dengan metode berfikir deduktif dan induktif. Hasilnya adalah, bahwa dalam surat Luqman ayat 13-17 terdapat tiga konsep Pendidikan secara hirarkis, yaitu Pendidikan akidah, Pendidikan akhlak, dan Pendidikan Ibadah. Implikasinya adalah dalam jiwa anak akan tertanam jiwa tauhid, berbuat baik kepada kedua orangtua dan melaksanakan shalat dengan tepat waktu, dan mendapatkan ridha dari Allah SWT.
\end{abstract}

Kata Kunci: Pendidikan Islam, Surat Luqman, Pendidikan Keluarga

\section{PENDAHULUAN}

Pendidikan dalam undang undang sistem Pendidikan nasional didefinisikan sebagai usaha sadar dan terencana untuk mengembangkan potensi peserta didik (Depdiknas, 2003). Ahmad D. Marimba mendefinisikan pendidikan sebagai "bimbingan atau pimpinan secara sadar oleh sipendidik terhadap perkembangan jasmani dan rohani siterdidik menuju terbentuknya kepribadian yang utama" (Marimba, 1971, hal. 2).

Endang Syaifuddin Ansyari mendefinisikan Pendidikan sebagai proses bimbingan yang dilakukan oleh pendidik terhadap peserta didik dalam rangka tercapainya suatu tujuan pendidikan, dengan materi, waktu, metode dan perlengkapan yang ada (H. Endang Syaifuddin Anshari, 2004, hal. 149). Kesimpulan dari pengertian 
66 | Toha Makhshun

di atas pendidikan adalah usaha yang dilakukan untuk mengarahkan potensi anak didik menuju terbentuknya pribadi yang sempurna (Makhshun, 2018).

Dari kesimpulan tersebut kemudian dapat dipahami bahwa usaha yang dilakukan oleh pendidik kepada peserta didik dilakukan secara sadar, sengaja untuk mengembangkan potensi peserta didik, atau dalam Bahasa agama sering disebut dengan Fitrah. Fitrah menurut Quraish Shihab sebagaimana dikutip oleh Toha, dimaknai sebagai apa yang diciptakan oleh Allah pada manusia yang berkaitan dengan jasmani dan akalnya (serta Ruhnya) (Makhshun, 2018), fitrah inilah yang harus dijaga supaya tidak keluar dari tujuan penciptaan manusia, salah satu upaya untuk menjaga fitrah melalui Pendidikan, sehingga dapat mencapai kebahagiaan di dunia dan akhirat.

Sedangkan ketika berdiskusi tentang dasar pendidikan Islam adalah sesuatu yang mendasari dan melandasi setiap aktifitas pendidikan dalam Islam (Achmadi, 2010, hal. 83), yang akan menjadi dasar pijakan pendidikan Islam dalam kerangka tercapainya sebuah tujuan pendidikan, sehingga atara dasar dan tujuan tersebut tidak dapat dipisahkan, karena keduanya menyangkut sesuatu yang sangat fundamental dan ideal.

Sebagai sesuatu yang fundamental dan ideal, dasar pendidikan akan menopang unsur-unsur dan komponen-komponen lain dalam pendidikan, seperti materi, metode, media, dan prarana lainya, sehingga situasi dan keadaan berubah seperti apapun, kalo ditopang dengan dasar yang kuat maka pendidikan tidak akan tergoyahkan dan tidak akan terpengaruh zaman.

Sebagai seorang muslim, yang menyakini Islam sebagai pandangan hidup dengan menjadikan al-Qur'an dan sunnah sebagai sumber pokok ajaran Islam, menjadikan keduanya sebagai dasar pendidikan Islam adalah suatu keniscayaan, yang juga didukung dengan rakyu.

Nilai-nilai yang terdapat dalam al-Qur'an dan sunnah, baik yang bersifat dasar maupun instrumental, maka harus dipilih sebagai dasar pendidikan Islam, yaitu keimanan atau tauhid. Nilai tauhid inilah yang menjadi dasar dan pondasi seluruh ajaran Islam, termasuk salah satunya adalah pendidikan. 


\section{HASIL DAN PEMBAHASAN}

\section{A. Tujuan Pendidikan Islam}

Tujuan adalah sesuatu yang diharapkan tercapai pada akhir kegiatan atau cita cita akhir kegiatan (Badaruddin, 2009, p. 39) Pendidikan sebagai proses membentuk kepribadian anak memiliki tujuan yang sejalan dengan penciptaan manusia, karena pendidikan diarahkan untuk menyempurnakan tujuan penciptaan manusia, sehingga dapat dijabarkan tujuan pendidikan Islam sebagai berikut:

1. Manusia yang Bertakwa

Manusia adalah sebaik-baik ciptaan Allah, diabanding makhluk yang lainnya. Kesempurnaan manusia sebagai makhluk Allah terletak pada akal yang dimiliki oleh manusia, sehingga dengan akalnya tersebut manusia dapat membedakan mana yang baik dan buruk, sehingga mampu melaksanakan perintah dan menjauhi larangan Allah. Akal manusia dilatih dan diasah melalui pendidikan, yang akhirnya akan membawa manusia kepada tujuan penciptaan manusia, yaitu selalu beribadah kepada Allah (Achmadi, 2010, hal. 56).

Ibadah dalam Islam tidak sekadar yang bersifat khusus (mahdhah) yang ketentuan pelaksanaannya sudah ditentukan oleh Allah, tetapi juga mencakup ibadah umum (ghaira mahdhah) yang ketentuannya masih memerlukan penafsiran. Ibadah mahdhah tidak dapat dipisahkan dengan ibadah ghaira mahdhah, karena hikmah ibadah mahdhah harus teraktualisasi dalam ibadah ghaira mahdhah, dengan potensi akal ini manusia tujuan penciptaan manusia menjadi sempurna, yaitu beribadah kepada Allah) (Kemenag, 2005, hal. 523). Menyembah atau "ibadah" dalam pengertian yang luas adalah mengembangkan sifat sifat Allah dalam diri manusia sesuai dengan petunjuk Allah (Langgulung, 2003, p. 299)

2. Wakil Allah di Muka Bumi

Pendidikan dalam Islam selain agar manusia selalu beribadah kepada Allah, juga memiliki tujuan untuk membawa manusia kepada fungsi kekhalifahan di muka bumi sebagaimana dalam Qs.al-Baqarah [2]:30 (Kemenag, 2005). Manusia sebagai wakil Allah dimuka bumi dituntut untuk melakukan pelestarian, pemeliharaan terhadap seluruh makhluk yang ada di muka bumi ini, yaitu imarotul ard (Shihab, 2000, hal. 272-273), sehingga manusia mampu 
menggali potensi-potensi alam agar dapat terhindar dari kerusakan lingkungan dan mendatangkan kebaikan bagi seluruh alam (Achmadi, 2010).

Alam beserta isinya diciptakan dan ditundukkan oleh Allah dalam rangka membantu manusia dalam menjalankan fungsi imarot ard (Qs. Hud:60) (Kemenag, 2005). Manusia diperintahkan untuk membangun alam sesuai dengan tujuanya, yaitu memelihara dan melestraikannya (Shihab, 2000), karena kecenderungan manusia dimuka bumi inilah adalah berbuat kerusakan dan menumpahkan darah (QS.2 :30).

Hal ini mengisyaratkan bahwa pelaksanaan tugas kekhalifaan, sedikit banyak membawa dampak negative, yang dapat ditanggulangi manakala manusia mengindahkan petunjuk Allah (Shihab, 2000). Diantara kerusakan yang diakibatkan oleh manusia karena keserakahan antara lain menebang pohon secara liar, pembunuhan, pencurian, mengurangi takaran, pemborosan, foya-foya dan penipuan (Shihab, 2000). Fungsi manusia sebagai wakil Allah dimuka bumi adalah menghilangkan atau setidaknya meminimalisir hal tersebut.

3. Bahagia Dunia Akhirat

Bahagia dunia akhirat merupakan tujuan hidup yang dicita citakan setiap muslim, yang selalu dibaca setiap saat, yaitu bahagia di dunia, bahagia di akhirat dan terhindar dari adzab neraka (QS. Al-Baqarah :200-2002) (Kemenag, 2005). Doa tersebut merupakan doa yang palin popular dikalangan umat Islam, bahkan sering dibaca Nabi Muhammad Saw sat thawaf dan kesempatan diluar thawaf (Shihab, 2000, p. 109).

Tentu doa tersebut tidak serta merta terkabul secara instan, tetpi membutuhkan proses, yaitu doa yang diikuti dengan usaha serius sesuai dengan doa dimaksud (Achmadi, 2010). Hasanah di dunia dan di akhirat, di dunia mencakup mantapnya iman, sehat afiat (berfungsinya anggota tubuh sesuai tujuan penciptaan), rezeki yang memuaskan, keluarga yang shaleh, Sedangkan di akhirat adalah ketentraman, hisab yang mudah, dan beertemu Allah (Shihab, 2000, hal. 111). 


\section{B. Materi Pendidikan Islam}

Dalam surat Luqman Ayat 13 - 17 disebutkan:

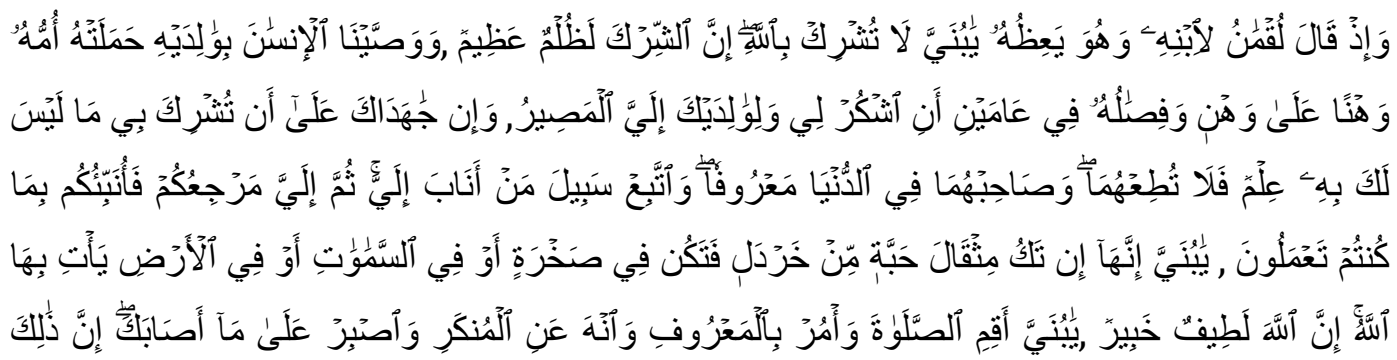

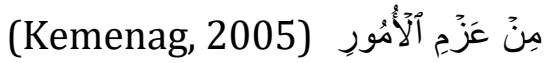

Berdasarkan ayat di atas, dapat dipahami:

1. Pendidikan keimanan/ Akidah

"Iman adalah kepercayaan yang mendalam di dalam hati dengan penuh keyakinan, tak ada perasaan syak (ragu-ragu) serta mempengaruhi orientasi kehidupan, sikap dan aktivitas keseharian" (Qardawi, 2000, hal. 27). Al Ghazali mengatakan "iman adalah megucapkan dengan lidah, mengakui benarnya dengan hati dan mengamalkan dengan anggota badan" (Zaenudin, 1991, hal. 97). Pendidikan keimanan termasuk aspek pendidikan yang patut mendapat perhatian yang pertama dan utama dari orang tua, karena keimanan/ akidah tauhid sebagai dasar pijakan dan landasan utama dalam pendidikan anak (Muflihin \& Madrah, 2019).

2. Pendidikan Akhlak

Secara terminologi "Akhlak adalah sifat yang tertanam dalam jiwa yang menimbulkan perbuatan-perbuatan dengan mudah tanpa memerlukan pemikiran dan pertimbangan." (Ghazali, 1989, hal. 58). Dari definisi di atas dapat diambil pemahaman bahwa akhlak adalah sesuatu yang muncul secara spontan tanpa berpikir Panjang untuk melaksanakan atau neloknya.

3. Pendidikan Ibadah

Para ulama mendefinisikan ibadah sebagai segala perbuatan yang dilakukan dengan maksud untuk mencapai Ridha Allah dan mengharapkan pahala di akhirat kelak (Fathurrohman, 2018). Ibadah merupakan bentuk ketundukan dan kepasrahan seorang Hamba kepada Penciptanya, yaitu Allah. Ketundukan da kepasrahan kepada Allah perlu dilatih dan dibiasakan oleh orang tua kepada anaknya, sehingga disiniliah pentingnya pendidikan ibadah, menyangkut ibadah khusus dan ibadah umum. Ibadah mencakup segala bentuk 
kegiatan, berupa perkataan atau perbuatan yang dilakukan orang islam dengan maksud mencari ridha Allah.

\section{Analisis Pendidikan Islam Perspektif QS. Luqman Ayat 13-17 dalam Pendidikan Keluarga}

1. Pendidikan keimanan/Akidah

Akidah secara Bahasa berarti "ikatan" atau "sanguktan" yaitu seseorang yang terikat pada suatu ketetapan jiwa yang kuat (Fathurrohman, 2018), akidah sering disebut dengan iman, yaitu membenarkan dan menetapkan dengan hati, mengucapkan dengan lisan, dan melaksanakan dengan seluruh anggota badan.

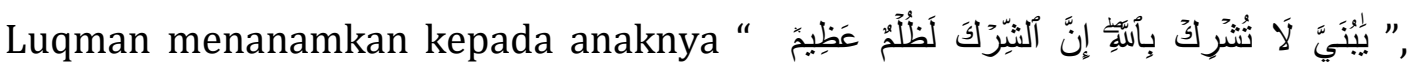
“jangan menyekutukan Allah, Karena sesungguhnya menyekutukan Allah adalah benar benar kedzaliman yang besar".

Luqman mengawali nasihat kepada anaknya dengan larangn untu menyekutukan Allah, yang mengandung maksud tentang ke Esaan Allah. Ayat tersebut memberikan penekanan kepada kita, bahwa hal pertama dan utama yang harus kita ajarkan kepada anak anak kita adalah akizah tauhid, yaitu keyakinan, bahwa Allah Esa, tiada sekutu bagi Allah, maka menyekutukan Allah adalah kedzaliman yang besar, tidak ada kedzaliman besar melebihi perbuatan syirik kepada Allah.

Pendidikan tauhid ini kita ajarkan kepada anak anak sejak dini, bahkan saat anak anak kita lahir, kita perdengarkan suara adzan di telinga kakan, dan iqamah di telinga kiri (Ulwan, 1981), supaya hal pertama yang didengar anak kita adalah kalimat tauhid, sehingga ini mengandung maksud, bahwa Pendidikan tauhid dimulai sebelum anak kita belajar apa apa.

2. Pendidikan Akhlak

Akhlak dapat diartikan sebagai budi pekerti, kelakuan, tabiat, perangai kebiasaan (Shihab, Wawasan Al-Qur'an, 2006). Dalam ayat 14 surat Luqman disebutkan "Dan Kami perintahkan kepada manusia (berbuat baik) kepada dua orang ibu-bapaknya; ibunya telah mengandungnya dalam keadaan lemah yang bertambah-tambah, dan menyapihnya dalam dua tahun. Bersyukurlah kepada$\mathrm{Ku}$ dan kepada dua orang ibu bapakmu, hanya kepada-Kulah kembalimu" (Kemenag, 2005). 
Ayat tersebut mengandung perintah kepada anak anak, supaya memiliki akhak yang baik kepada kedua orang tua, khususnya kepada ibu yang telah dengan susah payah di atas payah mengandung selama Sembilan bulan dan menyusui selama dua tahun, tentu ini pengorbanan yang luar biasa dari seorang ibu kepada anaknya, sehingga tidak heran kalo Ridho Allah Bersama ridho Orang Tua dan murka Allah Bersama murka orang tua.

Hal ini mengandung pemahaman bahwa batas ridho atau murka orang tua dengan Allah sangat tipis, sehingga kita jangan sekali kali membuat orang tua kita sakit hati, jangan pernah kita menyakiti hati orang tua. Di antara akhlak kepada orang tua adalah selalu taat kepada orang tua, kecuali oleh orang tua diperintahkan untuk menyekutukan Allah, maka kita dilarang taat kepada orang tua, tetapi hal tersebut tidak menghilangkan kewajiban kita untuk selalu

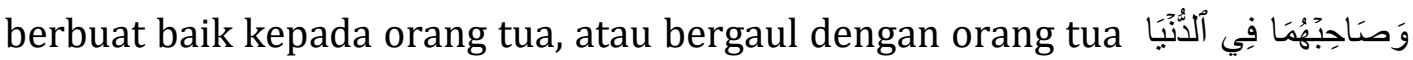
مَعَرُوفِّ yaitu bergaul dengan ma'ruf, yang memiliki arti sesuai dengan batas batas yang wajar.

Ihsan diderivasi dari kata حُسنْ/ حَسنْ yang mencakup segala bentuk kebaikan yang menjadikan orang tua senang karena mendapat nikmat menyangkut diri, jasmani dan keadannya" (Shihab, 2000, hal. 89). Kata ihsan sering digunakan dalam dua hal, pertama terkait dengan memberi nikmat kepada pihak lain, kedua terkait dengan perbuatan baik, sehingga ihsan memiliki makna lebih luas dari adil, karena ihsan berarti memperlakukan seseorang lebih baik dari perlakuanya terhadap kita (Shihab, Secercah Cahaya Ilahi, 2000). Kata bi sebelum ihsan mengandung makna yang dekat, artinya seorang anak harus selalu dekat dan merasa dekat kepada orang tua, Allah tidak menginginkan ada jarak antara anak dan orang tua, sehingga kata penghubung yang digunakan adalah bi bukan ila, karena ila mengandung arti "jarak" (Shihab, Secercah Cahaya Ilahi, 2000).

Berbuat baik kepada orang tua berdasarkan perintah agama islam adalah sopan santun kepada orang tua secara lisan dan perbuatan, mencukupi kebutuhan orang tua sesuai dengan kemampuan anak, tidak termasuk sesuatu yang mencabut kemerdekaan pribadi dan rumah tangga, atau pemaksaan keyakinan yang dilarang oleh agama. Dalam ayat yang lain yaitu surat al- Isra:23 disebutkan diantara berbuat baik kepada orang tua adalah tidak berkata kasar 
“"أف yang memiliki ari perbuatan kotor (Munir, 2008, hal. 44). Dan kata تنهرyang pada terusan ayat yang memiliki makna mengorek kulit yang mengakibatkan darah mengalir keluar. kata أفّ oleh Ibn Katsir ditafsirkan sebagai kata kata yang menyakiti hati, sedang نهر adalah tingkah laku yang penuh emosional dan kemarahan yang menyakiti orang tua.

Sungguh ini situasi yang amat sulit, di satu sisi ada larangan mengikuti perintah orang tua untuk menyekutukan Allah, disisi lain ada perintah untuk tetap berbuat مَعْرُوف kepada orang tua, sehingga pada ayat berikutnya

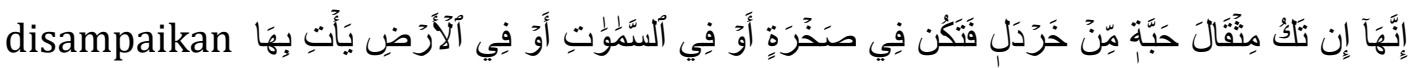

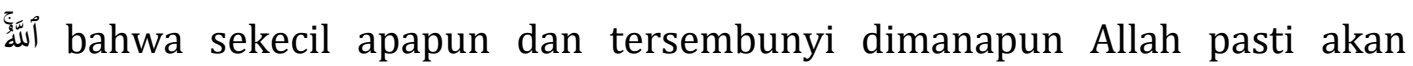
membalasnya.

3. Pendidikan Ibadah

Di dalam Al-Qur'an surat Luqman ayat 17 dijelaskan bahwa luqman memerintahkan kepada anaknya untuk mendirikan shalat dan amar ma'ruf nahi munkar. Perintah mendirikan sholat dalam surat luqman ini terletak setelah perintah tidak menyekutukan Allah dan perintah berbuat baik kepada orang tua, hal ini memiliki pengertian bahwa kewajiban melaksanakan sholat bagi anak anak kita setelah mereka mumayyiz. Shalat merupakan bagian dari salah satu ibadah khusus (ibadah mahdhah) yang secara aturan, tata pelaksanaan sudah diatur secara rinci dalam Islam. Shalat sebagai bukti dan batas seseorang dalam posisi sebagai seorang mukmin dan muslim.

Perintah shalat dengan kata أَقِقِ dapat dimaknai dengan melaksanakan shalat secara sempurna dan sungguh sungguh, sehingga orang yang shalat tidak dengan sempurna dan sungguh sungguh akan disebut sebagai orang yang lalai dalam shalat. Ada 4 perbuatan yang disejajarkan dalam ayat tersebut, yang keempatnya sama sama memiliki penekanan dan perlu komitmen kuat, yaitu mendirikan shalat, amar makruf, nahimunkar, dan sabar.

\section{KESIMPULAN}

Dari uraian dan penjelasan di atas, dapat disimpulkan bahwa pendidikan Islam perspektif surat Luqman ayat 13 - 17 adalah pendidikan keimanan (akidah), dan pendidikan akhlak, pendidikan ibadah (ubudiyah). Pendidikan akidah dalam surat Luqman secara tegas disampaiakn bahwa menyekutukan Allah adalah kedzaliman 
yang amat besar, sehingga kita harus memberikan pemahaman dan menguatkan keyakinan anak kita bahwa Allah adalah Tuhan yang Esa tiada sekutu baginya. Sedangkan pendidikan akhlak dalam surat Luqman dijelaskan pada ayat 14, 15, 16, di dalamnya mengandung perintah untuk bersyukur kepada orang tua, berbuat baik kepada orang tua, dan mentaati orang tua, selama orang tua kita tidak memerintahkan untuk menyekutukan Allah, dan Allah pasti akan membalas semua perbuatan kita walau sekecil biji sawi, dan mustahil perbuatan kita terlewat mesti tersembunyi dibalik batu di dalam bumi. Kemudian pendidikan ibadah dalam surat Luqman di jelaskan pada ayat 17 dan yang terkandung di dalamnya adalah : perintah mendirikan shalat, perintah amar ma'ruf nahi munkar, dan perintah bersabar atas segala musibah.

Urut urutan Pendidikan dalam surat luqman tersebut, kalo kita kaitkan dengan konsep Pendidikan secara umum, sungguh sudah dipraktekkan oleh negara negara yang secara akidah jauh dari Islam, seperti misalnya jepang, yang menerapkan pendidikan karakter sejak dini, Pendidikan karakter yang selama ini didengungkan adalah pendidikan akhlak dalam konsep surat luqman.

Implikasi dari nilai-nilai pendidikan Islam dalam surat Luqman ayat 12-19 adalah dalam jiwa anak akan tertanam jiwa tauhid, selalu bertakwa kepada Allah SWT, rajin beribadah dan beramal shaleh, berakhlakul karimah, berbuat baik kepada kedua orangtua/birrul walidain dan bersikap ramah kepada sesama dan dapat melaksanakan shalat dengan tepat waktu, maka dengan begitu kebahagian dunia dan akhirat akan tercapai dan mendapatkan ridha dari Allah SWT.

\section{DAFTAR PUSTAKA}

Abdul Majid Khon, M. (2012). Hadits Tarbawi. Jakarta: Kencana.

Achmadi, P. (2010). Idiologi Pendidikan Islam. Yogyakarta: Pustaka Pelajar.

Aly, H. N. (1999). Ilmu Pendidikan Islam. Jakarta: Logos.

Badaruddin, K. (2009). Filsafat Pendidikan Islam. Yogyakarta: Pustaka Pelajar.

Baharuddin, \& Makin, M. (2011). Pendidikan Humanistik. Yogyakarta: Ar-Ruzz Media.

Depdiknas. (2003). Undang-Undang Sisdiknas No. 20 Th 2003. Jakarta: Sinar Grafika.

Ghazali, A. H. (1989). Ihya Ulum ad-Din (Vol. III). Bierut: Dar al-Fikr. 
74 | Toha Makhshun

H. Endang Syaifuddin Anshari, M. (2004). Wawasan Islam: Pokok-Pokok Pikiran tentang Paradigma dan Sistem Islam. Jakarta: Gema Insani.

Kemenag. (2005). Al-Quran dan Terjemahnya. Bandung: CV Penerbit J_ART.

Makhshun, T. (2018). Model Pengembangan Kurikulum PAI SMP di Kota Semarang. Al Fikri, 97-114.

Marimba, A. D. (1971). Pengantar Filsafat Pendidikan Islam. Bandung: Al-Ma'arif.

Muflihin, A., \& Madrah, M. Y. (2019). Implementation of Al-Ghazali's Islamic Education Philosophy in the Modern Era. Al-Fikri: Jurnal Studi Dan Penelitian Pendidikan Islam, 2, 13-27. http://jurnal.unissula.ac.id/index.php/fikri/article/view/4012

Munir, A. (2008). Tafsir Tarbawi. Yogyakarta: TERAS.

Qardawi, Y. (2000). Merasakan Kehadiran Tuhan. Yogyakarta: Mitra Pustaka.

Shihab, M. Q. (2000). Secercah Cahaya Ilahi. Bandung: Mizan.

Sulaiman, F. H. (1993). Sistem Pendidikan Versi Al Ghazaly. Bandung: PT. Alma'arif.

Zaenudin. (1991). Seluk Beluk Pendidikan dari al-Ghazali. Jakarta: Bina Aksara.

Zakiah Daradjat, M. (2012). Ilmu Pendidikan Islam. Jakarta: Bumi Aksara. 